\title{
EDITORIAL
}

\section{Cadernos EBAPE.BR: changes and numbers of 2020}

\author{
Ph.D. Hélio ARThur Reis IRIgaray ${ }^{1}$ \\ PH.D. FABRICIO STOCKER ${ }^{2}$
}

\author{
1 Fundação Getulio Vargas (FGV ebAPE) / Brazilian School of Public and Business Administration, Rio de Janeiro - RJ, Brazil \\ ${ }^{2}$ Fundação Getulio VARgas / CAdernos EBAPE.BR, RIO de JANEIRO - RJ, BRAZIL
}

This is the first issue of 2021, and, therefore, let me begin by renewing my wishes for health, peace, and happiness to all readers, authors, reviewers, and assistants, without whom this journal would not exist.

Amid the many challenges over the past year, Cadernos EBAPE.BR went through important changes. In this editorial, I would like to share some of these changes and the journal's numbers for 2020.

The simplest change was the formatting rule. Since October 2020, we have adopted the American Psychological Association (APA) format for all new submissions. Thinking of the papers, dissertations, and theses of professional master's and doctoral programs, we created the Case Studies \& Teaching Cases section to present empirical cases, accompanied by teaching or research notes.

We also intensified the call for papers to elaborate thematic issues in 2020 , such as the one for studies on refugees. We now have two calls for papers open: Uncertain consumption practices in an uncertain future, organized by professors Russel Belk, Luís Pessôa, and Vitor Lima, and Infrastructure delivery and project management in developing and emerging economies, with guest editors Lavagnon Ika, Marcos Lopez Rego, Vered Holzman, and Nuno Gil.

These initiatives aim to give greater visibility to empirical studies and advance discussions in the areas of consumption and project management, considering their temporal and geographical peculiarities.

And this was only the beginning! In 2021, new calls for papers with very exciting themes are on the way!

In 2020, we had the pleasure of professors Russel Belk (York University/Schulich School of Business, Toronto, Canada), Lavagnon Ika (University of Ottawa/Telfer School of Management, Canada), Vered Holzman (The Academic College of Tel Aviv-Yaffo, Israel), and Gazi Islam (Grenoble École de Management, France) joining our editorial board.

Last year, a continuous desk review was also instituted, which reduced the average response time for the first editor's opinion to three weeks. I have personally dealt with these responses so that a channel of communication with all authors is always open. The average time between submission and the final editorial decision has been reduced to 5 months, while the average time between submission and publication is now 10 months.

In the last twelve months, the five issues published 76 articles from 197 authors, representing 67 Brazilian and seven international institutions. We received 255 submissions, 59 of which were written in English and one in Spanish.

The rejection rate in the desk review stage is $36 \%$, while the rejection rate after the ad hoc reviewing reached $47 \%$.

I would also like to introduce the esteemed Professor Fabrício Stockler, who is the new Associate Editor as of March. Professor Stockler will monitor the editorial flow and coordinate the journal's new Case Studies \& Teaching Cases section.

This first issue of 2021 starts with the article, Temporal and spatial dimensions of group entrepreneurship: the case of a craft fair as a community of practice, written by Ariane Latoski and Eloy Eros da Silva Nogueira, which proposes an analysis of the temporal and spatial dimensions of group entrepreneurial practice. The study addresses the processes of learning, training, and building capacity to master such practice while building the social structure where it is expressed. 
Next, Luana Jéssica Oliveira Carmo, Lilian Bambirra de Assis, Admardo Bonifácio Gomes Júnior, and Marcella Barbosa Miranda Teixeira present the critical essay Entrepreneurship as a neoliberal ideology. They discuss the neoliberal aspect of the discourse of entrepreneurship and its role of hiding the reality of the relationship between labor and capital.

In Citizen Relationship Management (CiRM): the past, present, and future of an emerging concept, Daniel Carvalho, Gisela Demo, Júlio Medeiros, and Fernanda Scussel analyze the scientific field of CiRM and its intellectual structure based on a literature review.

Fabio Faiad Bottini, Kely César Martins de Paiva, and Ricardo C. Gomes present the theoretical essay, Individual resilience, pleasure, and suffering at work and organizational links: reflections and perspectives of research for the public sector. The authors propose an integrative model that allows a broader and deeper view of the phenomena related to the three constructs and their possible interrelationships.

Epistemological surveillance and the Bourdieusian approach in the accounting field is a theoretical essay written by Mara Vogt, Marcia Zanievicz da Silva, and lone Ribeiro Valle. The objective is to analyze the coherence in using the Bourdieusian approach in accounting, and the authors bring elements from previous research to suggest directions for future studies.

Estéfanes Silva Oliveira, Marcia Prezotti Palassi, and Ana Paula Paes de Paula, in turn, analyze how the political conscience of a Brazilian sanitation company's employees generates a predisposition for these workers for or against the company's anti-privatization union movement, in their article Political consciousness and the likelihood of workers from a sanitation company to politically engage in anti-privatization actions in southeastern Brazil.

The article $A$ necessary discussion on consumer vulnerability: advances, gaps, and new perspectives, by Rosana Oliveira da Silva, Denise Franca Barros, Tânia Maria de Oliveira Almeida Gouveia, and Daniel de Oliveira Barata Merabet, examines how the concept of consumer vulnerability has been discussed in the marketing and consumer literature. The article seeks to identify the different perspectives and definitions in the main sources in which the topic is discussed, suggesting a comprehensive definition for vulnerability in marketing considering the vulnerability of other agents.

In Family farming policy network in Brazil, Luciana Nunes Goulart, Diego Mota Vieira, and Daniela Matias de Carvalho Bittencourt analyze public policy networks focusing on the National Family Agriculture Policy in Brazil.

Contributions to consolidate the new public governance: identifying dimensions of analysis, written by Breno Augusto Diniz Pereira and Ivan Beck Ckagnazaroff, proposes that New Public Governance uses tools from previous administrative models and emphasizes principles of democracy and legitimacy.

Following, Gabriela de Brelàz, Tamara Ilinsky Crantschaninov, and Laila Bellix describe the incorporation of the Open Government Partnership from their diffusion process and discuss the challenges of diffusion and institutionalization of a global policy at the local level, which occurred between 2013 and 2016, in their article Open Government Partnership in São Paulo City and the São Paulo Aberta program: challenges in the diffusion and institutionalization of a global policy.

In The legal regime of classified information in Brazil: theoretical and empirical problems and adequacy with a democratic constitutional order, Marcio Camargo Cunha Filho and Luiz Fernando Toledo Antunes suggest that non-submission to control mechanisms may allow overclassification of information by public agencies.

Aiming to discuss how the concept of reflexivity is conceived by Pierre Bourdieu, and how it develops and influences sociology, at the level of individuals, Bernard Lahire, Bruno de Souza Lessa, Fernando Dias Lopes and Célia Elizabete Caregnato present Reflexivity as a mediating element - The case of Francisco Milanez.

In the article, The state of the art of institutional capacity: a scoping review of the literature in Portuguese, Douglas Gomes Martins discusses the construct "institutional capacity" in its constitutive dimensions.

In this issue, we also have the guest article Meritocracy and competency-based people management model: utopia or organizational reality? written by Almir Rogério da Silva Souza and Isabella Francisca Freitas Gouveia de Vasconcelos, in which the authors present a literature review on the value of meritocracy in contemporary societies and organizations.

The "Case Studies \& Teaching Cases" section aims to encourage the production and use of teaching cases in Administration. The application of this teaching and learning methodology in undergraduate and graduate programs in Business and Public Administration contributes to greater dialogue between scientific and technological production. 
The purpose of the teaching case is for student managers to develop knowledge, skills, and attitudes to deal with the simulation, analysis, and resolution of managerial problems. The case is not a scientific article, although it may be a by-product of a research project. It must be structured to correspond with the narrative and purpose of the case itself. It must contain a problem situation, presenting information and actions taken by the company or individual that lead the student/reader to reflect and propose one or more possible solutions and identify flaws in the process.

The case may follow the Harvard style (average of 15 pages), dense and with detailed information about the organization, or short cases (up to 7 pages), still presenting a complex and adequate level of information.

This section was designed for professors, researchers who develop teaching cases, practitioners in the market, Master and Ph.D. scholars whose technical production in their academic and professional journeys contributes to the practice and reflections of the organizational management and world and can be used in teaching and research processes.

Submissions for the "Case Studies \& Teaching Cases" section will follow the continuous flow regime of Cadernos EBAPE.BR. The manuscripts must be divided into two parts, one presenting the case itself and the other with the teaching and/or research notes. The notes will be controlled by FGV and made available solely for professors and researchers in the area.

So, inaugurating the "Case Studies \& Teaching Cases" section, we present the work Consciousness or safety? Gender issues in an internal selection process, by Luiza Wanke Freitas, Vivian Luiz Coco, Lúcia Barbosa de Oliveira, and Ana Christina Celano Teixeira. In this case, the authors address the situation experienced by a manager of a team of six analysts from the financial board of a large public bank.

One of the team's senior analysts had been promoted and transferred to another area, and the manager has to choose one of his team's full analysts for the open position. After analyzing the candidates' skills and profile, the manager was convinced that one of them, Clarice, was the most prepared to take the job. At the same time, he knew that she could become pregnant in the near future and, if that happened, due to a special medical condition, she would be absent for a year, plus health and maternity leave. The manager is therefore faced with a dilemma. Should he limit his analysis to the candidate's skills, or should he also consider the repercussion among the other colleagues and the impact on the entire team's work if she became pregnant soon after the promotion? We hope that this will be the first of many teaching cases.

I wish you a pleasant read!

Ph.D. HÉLIO ARTHUR REIS IRIGARAY

EDITOR-IN-CHIEF

PH.D. FABRICIO STOKER

ASSOCIATE EDITOR

Ph.D. Hélio Arthur Reis Irigaray

ORCID: https://orcid.org/0000-0001-9580-7859

Ph.D. in Business Administration from FGV EAESP; Masters in Business Administration from PUC-Rio and Bachelor Degree in Economics from the University of Northern Iowa, USA. Assistant Professor at FGV EBAPE and at the Corporate International Masters (CIM) program of the Georgetown University, Washington, USA. Leader researcher on the theme Diversity and Labor Relations, in the area of Work Management of the National Association of Graduate Studies and Research in Administration (ANPAD). E-mail: helio.irigaray@fgv.br

Ph.D. Fabricio Stocker

ORCID: https://orcid.org/0000-0001-6340-9127

Ph.D. in Administration from FEA/USP and Ph.D. in Management from the Erasmus University of Rotterdam; Visiting researcher at the University of Amsterdam; Master's in Administration from UFPR and specialization at FGV and London Business School; Economist and Administrator; Professor at FGV on the online undergraduate programs, MBA, and graduate programs. Associate Editor of the journal Cadernos EBAPE.BR (FGV). E-mail: fabricio.stocker@fgv.br 